\title{
2.5. HOW CAN CORPORATE SOCIAL RESPONSIBILITY BE PERCEIVED IN MULTINATIONAL COMPANIES? - A CASE STUDY
}

\begin{abstract}
Summary
First decade of the $21^{\text {st }}$ century can be characterized by rapid development of global society as well as by remarkable growth of global issues, both on environmental and social level. These issues have strengthened the necessity to develop and apply more systematic and sustainable approach towards business activities realized on international and local level. Therefore, Corporate Social Responsibility (CSR) has become an important tool, many companies have decided to apply considering their business activities on local as well as global markets. The aim of this article is to evaluate the perception of corporate social responsibility in the context of business internationalization at the selected company. We will focus on its appraisal in four main areas especially on the area of human resources, the environmental area, the business area and the area of local community. The first part of article includes theoretical knowledge which was obtained by the study of professional home and foreign literature, which delimit the area of corporate social responsibility and its individual parts, international management and business, globalization and internationalization of the business activity, business ethics and the ethics code. To meet the set target, we obtained the primary dates by a questionnaire method. This questionnaire was filled in by the employees of the company in an electronic form. The principal part of this article is a part aiming at the work results which includes a brief characteristic of the parent and subsidiary company, evaluation of the questionnaire including clear tables, graphs and statistical evaluation of the four set research theories. In conclusion, we evaluated the results from the questionnaire in total and suggested recommendations for the oncoming company business activity.
\end{abstract}

Keywords: international management and business, business ethics, internationalization, corporate social responsibility

\section{Introduction}

The main reason for the idea of corporate social responsibility was the question of how to do a business well. This was meant in a way that would bring as many benefits to as many people as possible. Corporate social responsibility therefore means that companies should respect the needs of their stakeholders such as employees, customers, competitors, suppliers, community as well as environment while they also keep focused on profit. The pressure on enterprises towards socially responsible behaviour is reflecting the social, environmental and economic challenges that communities worldwide have to face nowadays. The beginning of modern concept of CSR dates back to 1950 Ss and since then it has become an inseparable part of strategic planning for many companies. In today's globalized world, an increasing number of customers expect to buy products that are not harmful to the environment and are produced in fair conditions for employees. Social responsibility of enterprises is focused on three main areas - economic, social and environmental all together encouraging sustainable development. Many multinational corporations have taken 
part in development of CSR concept. They understand that implementation of CSR activities brings along several benefits such as competitive advantage, improving company' image and reputation in the market, increasing loyalty of employees and customers and in the end also lower costs as a result. In today's competitive environment full of demanding requirements from customers, being a flexible company is crucial. Concept of CSR plays an important role in this environment and represents a great opportunity for companies to become successful while also making world a better place explains Kovácsová (2015). The corporate social responsibility of firms, trying to enter new markets and internationalize their production, is a hot topic, nowadays. Decision makers are solving issues connected to the profit maximization, quality improvement, lowering costs, outsourcing, resources recovery, and satisfaction of stakeholders. Companies, operating on more than one market, have to adapt their production processes and management to the requirements of the several markets. International employees are more than a common thing in multinational corporations and managers have to respond to the constant changes caused by implementation of new technologies and innovations. For this concept, mainly known under the English name Corporate Social Responsibility, there are a number of definitions in the literature, and currently there is no one global definition. One of the most important is the definition by the European Commission, which describes the social responsibility as a "concept whereby companies integrate social and environmental considerations into daily business operations and interactions with corporate stakeholders". (EC, 2011) The European Commission's definition highlights the voluntary nature of this particular concept and the impact on the functioning of the company's stakeholders.

Currently, there is no uniform global definition for the concept of CSR. This is mainly due to the fact that CSR is on voluntary basis and does not have strictly defined boundaries.

The three best-known definition of CSR:

- The EU Green Paper defines CSR as "a concept whereby companies integrate social and environmental concerns in their business operations and in their interaction with their stakeholders on a voluntary basis".

- The World Business Council for Sustainable Development (WBCSD): "Corporate Social Responsibility is the continuing commitment by business to behave ethically and contribute to economic development while improving the quality of life of the workforce and their families as well as of the local community and society at large."

- Business for Social responsibility defines CSR as: "Operating a business in a manner that meets or exceeds the ethical, legal, commercial and public expectations that society has of business." (Pavlík and Bělčík, 2010)

Ubrežiová and Gurská (2013), Mura and Buleca (2014) and Ubrežiová and Horská (2011) explain that corporate social responsibility includes the economic, legal, ethical, and philanthropic expectations placed on organizations by society at a given point in time. Authors mention the concept Carroll's four-part model of CSR.

- Within the economic responsibility, companies have shareholders who demand a reasonable return of their investments, they have employees who want safe and 
fairy paid jobs, they have customers who demand good quality products at a fair price, etc.

- By legal responsibility, we understand demands that business abide by the law and "play by the rules of the game".

- Ethical responsibilities oblige corporations to do what is right, just, and fair even when they are not compelled to do so by the legal framework.

- Philanthropic responsibilities as the fourth level incorporates activities that are within the corporation's discretion to improve the quality of life of employees, local communities, and ultimately society in general.

According Wach (2014), Skýpalová and Kučerová (2014) as well as Mihalčová et. al. (2013), many multinational corporations and small and medium sized enterprises have taken part in development of CSR concept. According to Čierna (2008) corporate social responsibility of companies and individuals is now becoming one of the most serious issues of our planet. It is an area that is increasingly becoming an important part of corporate strategy. The philosophy of corporate social responsibility concerns business development, ethics, morality, nature, and hope for present and future generations. CSR is a concept by which firms admit their co-responsibility for the condition and functioning of the society. Many businesses, regardless of their size, importance and position in the marketplace, are now trying to behave more responsible - ethically, socially and environmentally acceptable to its stakeholders. Such behaviour brings them undoubtedly many effects in the long run, such as better economic performance, the effect of reputation, customer satisfaction and employee loyalty. Responsible behaviour is not a short-term issue; it has to be long-term and consistent business philosophy, overlapping all the business activities. Applying the concept of CSR often requires fundamental changes in thinking of owners, managers and employees. Musová (2013). They understand that implementation of CSR activities brings along several benefits such as competitive advantage, improving company' image and reputation in the market, increasing loyalty of employees and customers and in the end also lower costs as a result. In today's competitive environment full of demanding requirements from customers, being a flexible company is crucial. Concept of CSR plays an important role in this environment and represent a great opportunity for companies to become successful while also making world a better place. Veber et al. (2011) supports the previous statements and adds that companies applying the concept of CSR integrate social and environmental considerations into their business activities in collaboration with their stakeholders on a voluntary basis. Firms complement their traditional economic objectives by the objectives that take into consideration the benefits of society (expansion of the company's strategy by environmental, social, ethical and community aspects). The concept works on the principles of charity, volunteering and partnership. According to Hambalková and Lušnáková (2012), the argument, which is often used against the application of social responsibility, is that companies are simply not able to pay the increased cost of its implementation. Yet corporate responsibility ultimately has a direct effect on reducing the environmental and production costs, to attract and retain a skilled workforce and also to discover new niches or even new markets. One of the benefits of corporate social responsibility is risk management. Enterprise, which perceives the surrounding 
environment and takes into account its interests, is better able to anticipate potential risks and promptly respond to changes that may occur and have an impact on the success of the enterprise based on Hohnen (2007). Other numerous benefits of applying CSR concept according to Hambalková and Lušnáková (2012) include:

- helps to increase profits (consumers prefer to buy products from socially responsible companies);

- helps to reduce costs (resource efficiency);

- increase the long-term potential of the company (the company supports the growth conditions such as goodwill);

- supports innovation (stimulation of innovative thinking and procedure);

- allows better management of human resources (reconciliation of family and working time, training and education, anti-discrimination policy);

- conditions to attract investors (investment funds choose opportunities and economic, social and environmental factors, as CSR criteria mean safety).

According to Kachaňáková (2010), in today's dynamic environment, which is accompanied by the globalization trends, organizations are required to be identified and distinguished from each other at the first glance. Each organization is being presented daily in some way to the surrounding environment. This is happening through its various activities, such as hiring and releasing employees, product manufacturing, service providing, marketing, etc. The ways in which the organization represents itself for the purposes distinguishing from others and becoming well known can be called the identity of the organization or corporate identity. It is significantly influenced by strong, clearly defined and presented organizational culture. The author adds that the identity of the organization is a purposefully shaped strategic concept of the internal structure of the elements, their operation and external presentation of the particular organization. The defining element of identity is the vision of the organization.

\section{Methodology}

The main objective of this article is to evaluate the perception of corporate social responsibility in the context of business internationalization at the selected company. In order to achieve this major objective, it is necessary to create supportive partial objectives. The theoretical part gathers the necessary information about terms such as multinational company, corporate culture and corporate social responsibility and serves as a basis for the practical part. The practical part is dedicated to the analysis of the selected company and its CSR activities, as well as the evaluation of the survey findings in relation to the mentioned issues.

For elaboration of the theoretical part of the article, secondary sources such as books, papers and information available on internet websites were used. Both primary and secondary sources served as the basis for the practical part of the thesis:

- Primary sources: gathered from the survey about CSR understanding taken on the sample of 100 respondents.

- Secondary sources: gathered from the company's internal materials, for instance annual reports, Global Responsibility reports, website and other publications.

The following hypotheses were formulated during the final article elaboration: 
- Hypothesis 1: We assume that there is a relation between the knowledge of CSR concept and education level achieved.

- Hypothesis 2: We assume that there is a relation between the preference of particular CSR aspect and gender of the respondent.

- Hypothesis 3: We assume that there is a relation between the familiarity of the selected company and age of the respondent.

To test if these hypotheses are truthful, we used the statistical method called $\chi^{2}$ test of square contingency. Is a test for nominal data for two independent sets and is used to test hypotheses concerning the existence of dependencies between own questions and classifying variables. For illustration, we will explain the results from evaluation of hypothesis 2 .

The survey included four classification questions about respondents' gender, age, education and nationality. The second part of the questionnaire was focused on the general knowledge of respondents about the concept of CSR using both polytomic questions with multiple choice and trichotomic closed questions. The last part of the survey was oriented on perception of selected company and its CSR efforts by respondents. In this part also scale questions were used to reflect the importance of particular factors. The data acquired from the questionnaire were statistically processed in Microsoft Excel and displayed by using both graphical and numerical means.

As a part of research, we set the following hypotheses in relation to the research in selected company:

- We assume that there is a relation between the knowledge of CSR concept and education level achieved.

- We assume that there is a relation between the preference of particular CSR aspect and gender of the respondent.

- We assume that there is a relation between the familiarity of selected company and age of the respondent.

\section{Results and discussion}

The aim of the research was to analyse the level of knowledge that respondents have about corporate social responsibility in general and at the selected company. For this purpose, the method of anonymous questionnaire was chosen and this was distributed among 100 respondents electronically. The research was conducted between at the beginning of 2015. The survey included four classification questions about respondents' gender, age, education and nationality. The second part of the questionnaire was focused on the general knowledge of respondents about the concept of CSR using both polytomic questions with multiple choice and trichotomic closed questions. The last part of the survey was oriented on perception of the selected company and its CSR efforts by respondents. The questionnaire consists of 18 questions and was anonymous. The first question was aimed to find out the gender structure of the respondents. The questionnaire survey was filled in by 100 respondents, of whom 66 were women and 34 were men. Based on the main goal of article, we wanted to find out which of the three CSR aspects do respondents prefer. Social aspect was chosen as the most important with 62 respondents believing in its importance. 30 respondents think Environmental aspect is the most important of the 
three and only 8 people believe Economic aspect should come first before environmental and social initiatives of a company. Within the selected question for respondents, e.g. "According to your opinion, what is the most important aspect for an organization regarding CSR" we also set the second hypothesis where we assume that there is a relation between the preference of CSR aspect and gender of respondents. We tested the following options:

- H0: There is no relation between the preference of CSR aspect and gender of respondent.

- H1: There is a relation between the preference of CSR aspect and gender of respondent.

Table 1. Relation between the preference of CSR aspect and gender of respondent

\begin{tabular}{|c|c|c|}
\hline \multirow{2}{*}{ Outcomes } & Chi table & Chi calculated \\
\cline { 2 - 3 } & 1,3187 & 5,9915 \\
\hline
\end{tabular}

Source: own processing based on (Kovácsová, 2015)

Based on the outcome of the chi-square test of square contingency (Tab. no.1) we do not reject the zero hypothesis which means that at the significance level of $\alpha=0.05$ there is no relationship between the preference of CSR aspect and gender of respondent. The another question was aimed to find out what are the main reasons for a company to involve in CSR activities. Respondents could choose maximum three of eight answers. Intentions to improve company's image were selected as the most probable reason leading company to social responsibility with 74 respondent choices. The other two highly ranked options were to increase employees' satisfaction and loyalty and to gain competitive advantage. The least probable of all possible reasons for company to adopt CSR activities was cost savings with only was opted by 5 respondents (see Figure 1).

Figure 1: What do you think are the reasons for a company to adopt CSR?

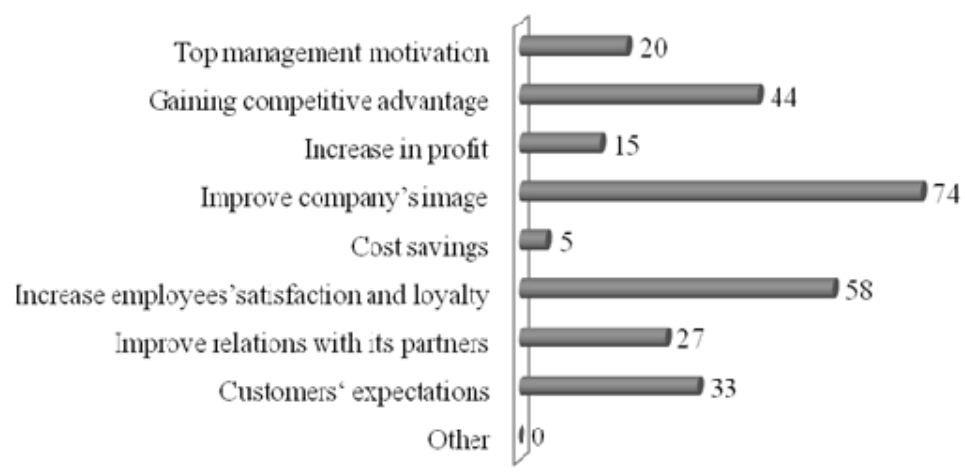

Source: own processing based on Kovácsová (2015)

On the other hand, other question deals with barriers that prevent a company from adoption of responsible behaviour. Two options were selected as the greatest barrier. Equally 30 respondents think that lack of management's motivation and high cost of 
implementation of CSR often hinder enterprises from socially responsible initiatives. $25 \%$ of respondents believe that insufficient knowledge about the topic could be a significant barrier for organizations as well. Two respondents thought of other, not stated, barriers and these were evaluated as simply no interest of a company in CSR and profit preference. As Kovácsová (2015) states, in today's fast changing business environment, companies need to be flexible to adapt to these changes. They should understand that doing business nowadays means more than just generating profit and their activities need to be beneficial for the society as a whole. The concept of corporate social responsibility represents voluntary efforts of an enterprise in following three areas - economic, social and environmental. CSR influences the corporate image of an organization and represents competitive advantage, added value and long-term prosperity for companies that have decided for its application.

On the other hand, the next question deals with barriers that prevent a company from adoption of responsible behaviour. Two options were selected as the greatest barrier. Equally 30 respondents think that lack of management's motivation and high cost of implementation of CSR often hinder enterprises from socially responsible initiatives. $25 \%$ of respondents believes that insufficient knowledge about the topic could be a significant barrier for organizations as well. Two respondents thought of other, not stated, barriers and these were evaluated as simply no interest of a company in CSR and profit preference (Figure 2).

Figure 2: Barriers of Corporate Social Responsibility
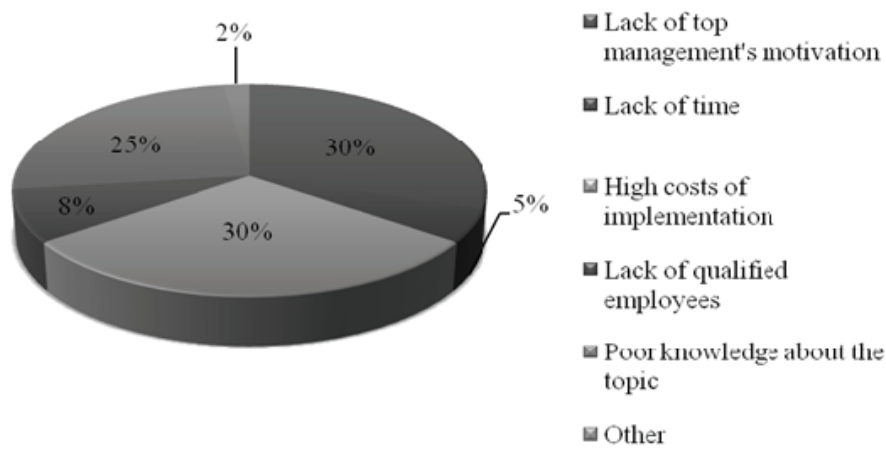

Source: own processing based on Kovácsová (2015)

Following questions are oriented to find out if respondents are familiar with the term of CSR and what do they understand under this concept. In recent years, the concept of corporate social responsibility received awareness and interest of companies and general public around the world. When asked "Have you ever met with the term Corporate Social Responsibility?"

- 51 out of 100 respondents claimed that they are familiar with this term and know what is the concept about.

- 25 respondents have already come in touch with CSR but they are not sure about it significance.

- 6 respondents who do not know whether they have ever met with the term. 
- 18 respondents are not familiar with the concept at all. The results are rather positive and we can assume that socially responsible behaviour of the companies is attracting increasing attention of the public.

Within this question, we set the first hypothesis where we assume that there is a relation between the knowledge of CSR concept and education level of respondents. We tested the following options:

- H0: There is no relation between the knowledge of CSR concept and education level of respondents.

- H1: There is a relation between the knowledge of CSR concept and education level of respondents.

Table 2: Relation between the knowledge of CSR concept and education level

\begin{tabular}{|c|c|c|}
\hline \multirow{2}{*}{ Outcomes } & Chi table & Chi calculated \\
\cline { 2 - 3 } & 16,9190 & 10,5576 \\
\hline
\end{tabular}

Source: own calculations based on Kovácsová (2015)

Based on the outcome of the chi-square test of square contingency (see table 2) we do not reject the zero hypothesis which means that at the significance level of $\alpha=0.05$ there is no relationship between the knowledge of CSR concept and achieved education level of the respondent. Next question provides us with a more detailed information about what do respondents understand under corporate social responsibility.

Figure 3: What do you understand under Corporate Social Responsibility

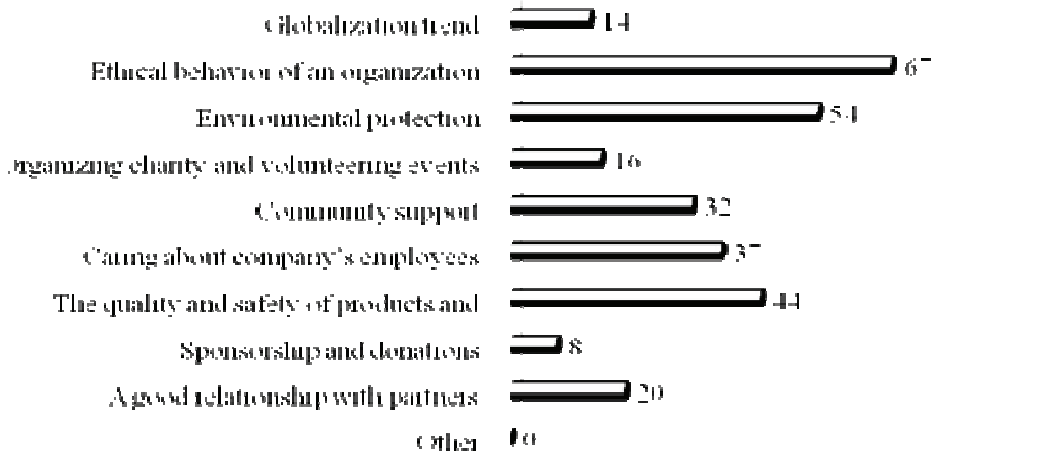

Source: own processing based on Kovácsová (2015)

There were nine specific ideas of perceiving this concept and respondents could choose maximum of three answers. Out of total respondents, 67 think Ethical behaviour of an organization best characterizes the concept of CSR. Environmental protection was placed as second important activity of socially responsible enterprises with 54 respondents 'choices, followed by The quality and safety of products and services provided by a company which ended up with 40 respondents choosing i tas one of the options. 37 respondents understand under CSR Caring about company's employees as one of the relevant explanations, while 32 consider Community support 
as an area that should not be ignored by companies. A good relationship with business partners is understood by as CSR initiative by 20 respondents. 16 of those asked think that Organizing charity and volunteering events is an important activity within the responsible behaviour followed by Globalization trend which is understood with 14 answers and Sponsorship and donations with only 8 respondents considering it as a typical CSR activity as you can see on Fig 3 .

The upcoming set of questions form a part of our survey, too. They were aimed to analyse the perception of selected company within the concept of CSR as well as importance of particular activities company carries out. Question „Do you know the selected company?" unveils whether respondents know the international coffee selected chain . 87\% know selected company and visited the coffee house at least once in their lives while $8 \%$ of respondents have never been in company store but are aware of the company's existence. The remaining 5\% of respondents do not know the company. Results point out the great brand awareness of the company as only $5 \%$ of respondents do not know the company which is not even operating in Slovakia. In connection with globalization trends we can support this fact by theoretical knowledge according to Veber et al. (2011) who explains which factors have supported the globalization trends in recent decades:

- tendency to limit the role of national territories, nationalism, protectionism and seek "borderless world"

- the development of logistics systems and communication systems that significantly "shorten the distance"

- changing political priorities of national governments, which can be characterized as a transition from welfare state to liberal oriented policy

- The introduction of investment incentives for foreign investors in the form of the creation of duty free zones, tax relieves, the provision of appropriate land grants to create jobs etc.

Within this question we set the third and last hypothesis where we assume that there is a relation between the awareness of selected company and age of respondents. We tested the following options:

- H0: There is no relation between the awareness of selected company and age of respondent.

- H1: There is a relation between the awareness of selected company and age of respondent.

Figure 4: Age of respondents

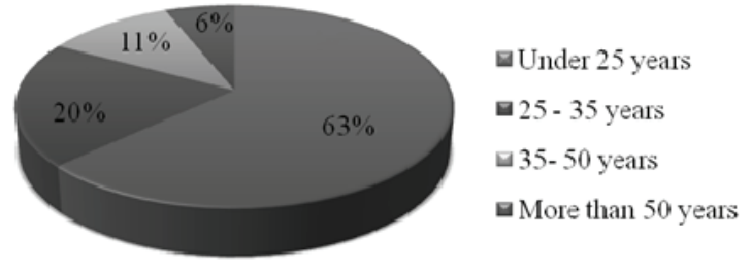

Source: own processing based on Kovácsová (2015) 
The major part is represented by young people aged under 25 years and this was $63 \%$. The second biggest part, $20 \%$, is created by the age group 25-35 years. $11 \%$ of respondents were aged between 35 and 50 years and finally $6 \%$ were people older than 50 years (Figure 4$)$ :

\section{Table 3: Relation between the awareness of selected company and age of respondents}

\begin{tabular}{|c|c|c|}
\hline \multirow{2}{*}{ Outcomes } & Chi table & Chi calculated \\
\cline { 2 - 3 } & 12,5916 & 18,3043 \\
\hline
\end{tabular}

Source: own processing based on Kovácsová (2015)

Based on the outcome of the chi-square test of square contingency we do reject the zero hypothesis and so accept the $\mathrm{H}_{0}$ which means that at the significance level of $\alpha=$ 0.05 there is a relationship between the awareness of selected company and age of respondent. Following, we calculate the Cramer contingency coefficient to find out how strong is this relationship. The coefficient equals 0,5018 pointing out the moderate interdependence between the two factors. Next question deals with frequency with which respondents visit company' stores. The majority of respondents, 65 , answered with occasionally. Other 27 respondents never visit the well-known coffee shop. One of the reasons could be that most of the respondents were of Slovak nationality and selected company does not operate its stores in Slovakia yet. 3 respondents selected company at least are quite regular customers who visit once per month and remaining 5 respondents are considered loyal customers visiting their favourite coffee place one time a week at least.

Question "What is your first thing you image under company?" asks about what does company evoke among respondents. Most respondents, 37\%, imagine high quality coffee while other $31 \%$ would rather Picture a customer oriented enterprise with friendly employees. $18 \%$ of respondents say that selected company represents nice environment to meet with friends and only $3 \%$ would label of selected company as a socially responsible enterprise at first place. There were 11 respondents who connect selected company with something other than provided options. Among these answers we could find opinions about overprices products when customers pay mostly for the famous brand name, American style and good marketing or simply an image of international coffee shop. Moving further, respondents were asked if they consider selected company to be a socially responsible enterprise. The greatest part of respondents do not know while 45 persons believe that the enterprise is involved in some socially responsible activities. Only 3 respondents think that selected company is not a socially responsible company.

Question "Protection environment" was subdivided into eight parts finding out opinions about importance of particular activities that selected company carries out within its CSR commitment. According to results, respondents find environmental protection, high quality of products and good care of employees as activities with the greatest importance to which selected company, according to its business nature, should especially dedicate attention (Figure 5). 
Figure 5: Importance of environment protection

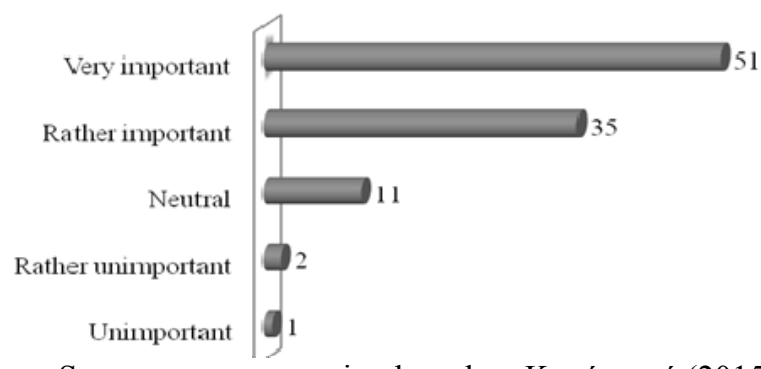

Source: own processing based on Kovácsová (2015)

Fair trade efforts (see Figure 6) of selected company were evaluated somewhere between very important and rather important. Other socially responsible initiatives were recognized as rather important including charity and donations events, interacting with communities, cultural diversity in the workplace and good relationship with stakeholders.

\section{Figure 6: Fair Trade efforts}

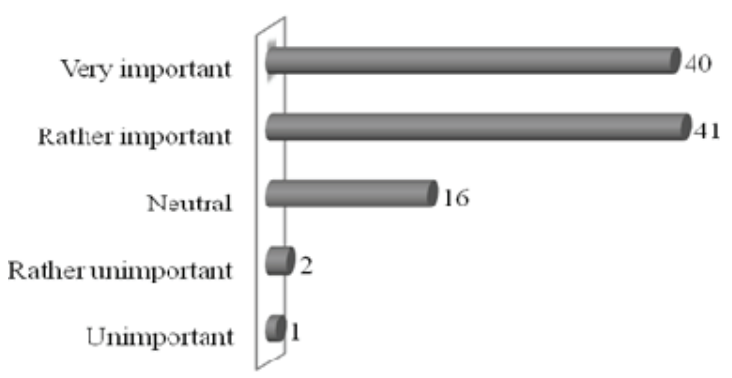

Source: processing based on Kovácsová (2015)

None of the stated activities was ranked of neutral or lower significance. A large multinational corporation such as selected company should put the efforts for environment protection in the first places of its Corporate Social responsibility activities to decrease its negative impact on nature. Similarly, majority of respondents - 51 - chose these activities as very important. Company set ambitious goals to achieve $100 \%$ ethical sourcing of its products in the future meaning that employees have fair conditions and remuneration while working and also no work of children is accepted. Respondents place importance of fair trade efforts of company somewhere between very important and rather important.

Most of respondents consider charity and donation events carried out by the company as rather important. Such activities are also very positive but should take place only after the more important responsible activities are performed such as environmental protection or high quality products etc. The high quality of products should be the in the greatest interest of company according to respondents from who 65 consider this factor very important. Interacting with community, similarly to organizing charity events, should be included within secondary responsible activities and majority of respondents consider such activities as rather important (Figure 7). 


\section{Figure 7: Importance of charity and donations}

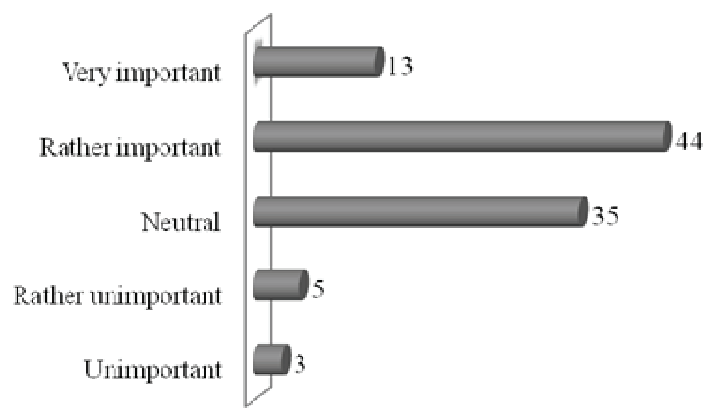

Source: own processing based on Kovácsová (2015)

Multinational enterprise put great emphasis on cultural diversity in the workplace and discrimination avoidance. $39 \%$ of respondents believe cultural diversity is rather important factor within CSR. To have a good relationship with customers, suppliers and other stakeholders included in company's operations a vital factor for every successful company. Respondents consider efforts for maintaining good relationship with these partners as rather important. However, efforts to practice responsible behaviour towards employees is chosen as one of the three most important CSR activities of selected company among environment protection and high quality products.

Question "Do you agree that selected company is one of the leaders company in the terms Corporate Social responsibility in the international market?" was aimed to find out whether respondents agree with the statement: "Selected company is one of the leader companies in terms of CSR in the international market". The majority of respondents do not know if the statement is true, while 36 respondents rather agree with the saying and 12 respondents strongly agree with the statement. 5 respondents do not think the statement about selected company as a leading CSR company is true and answered with rather or strong disagreement.

Last two questions "Do you believe responsible behaviour has helped selected company to build its reputation and firm image?" and "As a customer, would you prefer socially responsible company?" were aimed to find out if respondents believe socially responsible activities have helped selected company to build its image and if respondents themselves would prefer an enterprise which is involved in some of Corporate Social Responsibility activities and cares about the society and environment around it. $52 \%$ of respondents believe that responsible behaviour has probably helped selected company in building its reputation while $26 \%$ are sure about this being true. Other $15 \%$ of respondents do not know the answer for this question (Figure 8 ).

In practice, 64 respondents would surely prefer a socially responsible company and other 29 respondents would probably be of the same opinion (Figure 8). The answers clearly point out that CSR is becoming more familiar and important to customers who would probably sacrifice other factors such as price in order to get products from a socially responsible enterprise. 
Figure 8: Image of Selected Company

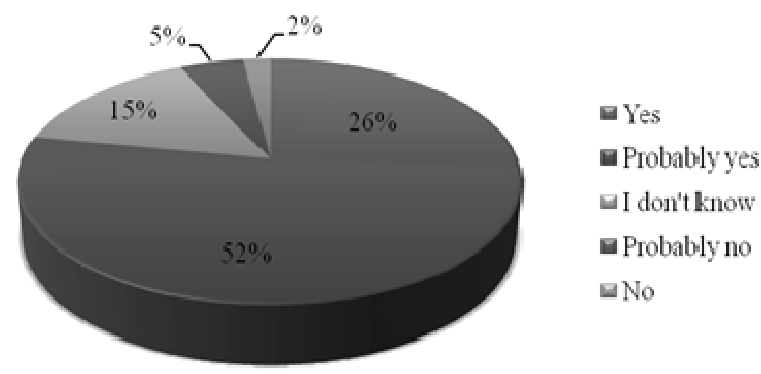

Source: own processing based on Kovácsová (2015)

As a multinational enterprise, selected company put great emphasis on cultural diversity in the workplace and discrimination avoidance. 39\% of respondents believe cultural diversity is rather important factor within CSR (Figure 9). In discussion with Fazekašová, M. (2006) corporate culture is a very complex phenomenon which is difficult to define, but significantly influences the long term success of the company. On the one hand it can be a source of strength for an enterprise and its competitive advantage, on the other hand, a stranglehold of its development. Corporate culture is about everyday life of a company and in particular about the behaviour of managers how they decide, solve conflicts, communicate, reward, motivate.

Hofstede (1991) defines organizational culture as core values, beliefs and assumptions that exist in the organization, patterns of behaviour that result from these shared meanings and symbols that express the connection between the assumptions, values and behaviour of members of the organization. It was confirmed by our research as it is introduced on Figure 9.

\section{Figure 9: Importance of cultural diversity in the workplace}

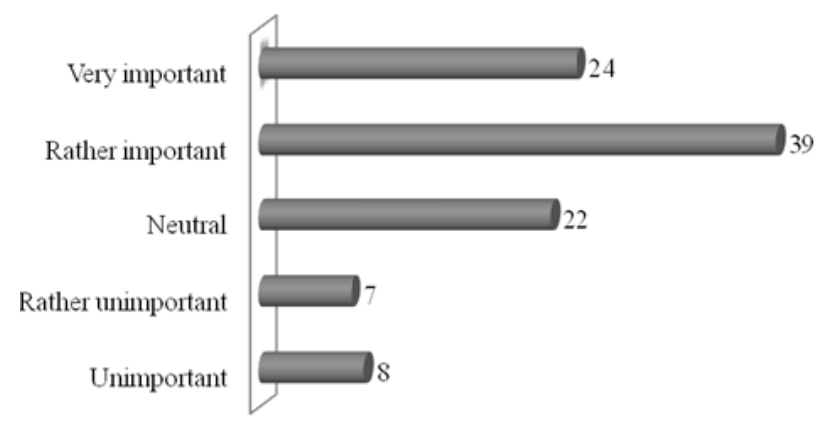

Source: own processing based on Kovácsová (2015)

\section{Conclusion and recommendation for further studies}

In today's fast changing business environment, companies need to be flexible to adapt to these changes. They should understand that doing business nowadays means more than just generating profit and their activities need to be beneficial for the society as a 
whole. The concept of corporate social responsibility represents voluntary efforts of an enterprise in following three areas - economic, social and environmental. CSR influences the corporate image of an organization and represents competitive advantage, added value and long-term prosperity for companies that have decided for its application.

The main objective of this diploma thesis was to analyse corporate social responsibility at the selected company and how these activities influence the firm image. We introduced the characteristics of the company, its corporate culture and responsible behaviour towards society in the practical part. We found out how selected company has become a successful multinational corporation. We focused on efforts of the corporation in terms of CSR in all social, environmental and economic areas. Following, we also analysed the customer awareness of CSR issues and their perception in selected company via questionnaire research and statistical processing of the results.

The survey involved the participation of 100 respondents of whose majority were women in terms of gender (66\%), those younger than 25 years $(63 \%)$ in terms of age, with some university degree $(68 \%)$ and of Slovak roots in terms of nationality. The research has shown that majority of respondents are familiar or has at least heard of term CSR which clearly indicate its increasing popularity and importance. We assumed that there could be a relation between this knowledge and education level of respondents, however, this assumption was incorrect meaning the knowledge of the concept does not depend on the highest education achieved.

The research also studied the customer understanding of CSR and unveiled that people expect companies to act beyond their legal responsibilities and commonly imagine ethical behaviour, environmental protection and high quality of products and services among three most common characteristics of responsible behaviour of enterprises. Majority of customers would prefer the social aspect aspirations however these preference does not depend on the gender of respondents as we assumed. The survey then pointed out in question, that improved corporate image is considered as the most powerful reason for applying the concept of CSR. This result support the overall focus of the thesis, which is the fact that responsible behaviour is perceived positively by the general public and creates better reputation and organizational image. On the other hand, there are several factors that discourage enterprises from doing this including lack of motivation, high cost of implementation or poor knowledge of the issue.

The closing part of the survey research analysed the perception of corporation within its CSR efforts and therefore represents the core and most important piece of the thesis. The vast majority of respondents (together 95\%) know of selected company which only proves the fact that it is the world's most famous coffee retailer. The awareness of company among respondents depends on their age and this assumption proved to be of mediate dependence. The survey also found out that most of the respondents visit Starbucks only occasionally which we suppose is the reason of fact that company is not present in Slovak territory and most of the respondents thus do not have a chance to visit more frequently.

The results of our research confirmed the success of this vision when respondents imagine not only high quality coffee but also customer oriented and friendly enterprise 
or nice environment to meet up with friends and colleagues when it comes to selected company. However, the survey results also pointed out that $52 \%$ of respondents do not know if the company incorporates itself in behaviour that is beneficial for society and environment. Based on the character of the enterprise, people believe that high quality products, good employees' treatment and protection of environment should be at the first place in selected company responsible commitment. Earlier, within the practical part of the thesis, we mentioned main CSR activities selected company tries to pursue. According to this knowledge, we can conclude that ethical sourcing of products, recycling challenges and employees (or "partners" as they are called) satisfaction are really the most important aims within company's responsible efforts. Moreover, 52\% of respondents believe that the CSR concept has probably helped selected company to build its reputation, while other $26 \%$ are absolutely sure about this fact. We can conclude that not only selected company, but every company that applies the corporate social behaviour brings benefits in the end not only for society, but definitely presents itself better in front of the customers and positively influence its corporate image. The results from last question of the survey proved us that $93 \%$ of respondents would quite surely or surely prefer a company that mind the society and environments issues and tries to bring benefits not only for itself.

Based on our findings, we can conclude that concept of CSR is becoming still more important and both people and companies are aware of this importance which opens the door for even greater application in the future. We hope that companies worldwide will understand the advantages of responsible behaviour and will use this sustainable advantage in long terms. There is a strong connection between the responsible attitude and increasing profit and improving image and we hope this fact will assure us brighter and more sustainable future.

\section{Acknowledgements}

This paper was created within the research project VEGA supported by the Ministry of Education, Science, Research and Sport of the Slovak Republic VEGA Corporate Social Responsibility (CSR) of the Slovak Enterprises in the context of Internationalization in Business. Project registration number 1/0044/13

\section{References}

1. Čierna, H. (2008): Spoločensky zodpovedné podnikanie a model výnimočnosti. Banská Bystrica: Univerzita Mateja Bela, 2008. 104 s. ISBN 978-80-8083-585-9

2. Fazekašová, M. (2006): Manažment teórii a praxi. [online]. [cit. 2015-06-27]. Available at: $<$ http://casopisy.euke.sk/mtp/clanky/3-4-2006/fazekasova.pdf $>$.

3. Gurská, S. (2012): Business Ethics in International Environment. In: Ubrežiová, I. - Gurská, S. (2012): International management and entrepreneurship. Nitra: SUA, 2012, pp. 43 - 57, ISBN 978-80-552-0941-8

4. Hambalková, M., Lušnáková, Z. (2012): Manažment obchodnej firmy. Nitra: SPU, 2012, 157p. ISBN 978-80-552-0894-7.

5. Hofstede, G. (1991): Cultures and Organizations: Software of the Mind. London: McGrawHill, Book Company, 1991, 296 p. ISBN 0-07-707474-2.

6. Hohnen, P. (2007): CSR: An implementation guide for business. [online]. [cit. 2015-06-27]. Available at: $<$ http://www.iisd.org/pdf/2007/csr_guide.pdf $>$. 
7. Kachaňáková, A. (2010). Organizačná kultúra. Bratislava: Iura Edition, 2010, 137 p. ISBN 978-80-8078-304-4.

8. Kovácsová, B. (2015): Firm Image in relation to Corporate Social Responsibility. (Diploma Thesis), Nitra: SUA, 2015, 99 p.

9. Mura, L., Buleca, J. (2013): Trends in international business of the Slovak small and medium food enterprises. Procedia-Social and Behavioural Sciences 110, 2014, pp.905-912

10. Obtulovič, P. (2004): Bioštatistika. 3. vyd. Nitra: SPU, 2004. 132s. ISBN 80-8069-432-X.

11. Pavlík, M., Bělčík, M. 2010. Společenská odpovědnost organizace. Praha: Grada Publishing, 2010, 176p. ISBN 978-80-247-3157-5.

12. Skýpalová, R., Kučerová, R. (2014): The Role of the State in Launching Social Responsibility in Small and Medium Enterprises. Acta Universitatis Agriculturae et Silviculturae Mendelianae Brunensis. 2014. sv. 62, č. 6, s. 1407--1415. ISSN 1211-8516.

13. Ubrežiová, A., Horská, E. (2011):. Perception and Approach towards Corporate Social Responsibility in SMEs: Case Study of Slovak and Czech Republic. In: PEFnet 2011 "European Scientific Conference of Ph.D. Students, Brno, 2011, pp. 1-7

14. Ubrežiová, I., Stankovič, L., Mihalčová, B., Ubrežiová, A. (2013): Perception of corporate social responsibility in companies of Eastern Slovakia region in 2009 and 2010. In Acta Universitatis Agriculturae et Silviculturae Mendelianae Brunensis. ISSN 1211-8516, 2013, vol. 61 , no. 7, p. 2903-2910

15. Veber, J. et al. (2011): Management: základy, moderní manažerské přístupy, výkonnost a prosperita. Praha: Management Press, 2011, 734 p. ISBN 978-80-7261-200-0.

16. Wach, K. (2014):.Internationalization and Globalization as the Wider Context of Europeanisation Process from the Macro- and Microeconomic Perspective. Horyzonty Polityki, Vol.5, no.10, pp.11-30 